\title{
PERLINDUNGAN HUKUM TERHADAP TENAGA KERJA BORONGAN BANGUNAN
}

\author{
(Study Kasus Villa Permata Ariza Jln. Karang Mas Sejahtera Kuta Selatan) \\ ${ }^{1}$ Selvianti Joenoes ${ }^{2}$ Desy Kuncahyati \\ ${ }^{1}$ Dosen Ilmu Hukum Universitas Teknologi Indonesia (UTI) Nusa Dua-Bali \\ Email: selvianti.uti@gmail.com \\ ${ }^{2}$ Mahasiswa Program Studi Ilmu Hukum Fakultas Hukum Universitas Teknologi \\ Indonesia (UTI) Nusa Dua-Bali
}

\begin{abstract}
Tenaga kerja merupakan sumber daya manusia sebagai modal utama serta pelaksanaan dari pembangunan masyarakat pancasila, oleh karena itu, tenaga kerja sebagai pelaksana pembangunan harus di jamin haknya, diatur kewajibannya dan dikembangkan daya gunanya selain itu dalam pembangunan nasional yang semakin meningkat, dengan resiko dan tanggung jawab serta tantangan yang dihadapi perlu untuk diberikan perlindungan, pemeliharaan Undang-Undang Nomor 13 Tahun 2003 tentang Ketenagakerjaan dan peningkatan kesejahteraan, sehingga menimbulkan rasa aman dalam bekerja.

Rumusan masalah "Bagaimana bentuk perlindungan Hukum Terhadap Pekerja Borongan Pembangunan dan faktor penghambat perlindungan hukum Villa Permata Ariza di Kuta Selatan". Tujuan penelitian "Untuk mengetahui bentuk Perlindungan Hukum dan faktor penghambat perlindungan Terhadap Pekerja Borongan Pembangunan Villa Permata Ariza di Kuta Selatan”.

Penulisan yang digunakan dalam penulisan skripsi ini adalah metode normatif yaitu penelitian hukum kepustakaan yang mengacu kepada norma-norma yang trdapat dalam peraturan perundang-undangan, pendapat para ahli hukum yang dituangkan dalam karangan buku dan putusan pengadilan.

Hasil penelitian perjanjian kerja yang dibuat secara lisan yang telah didominasi pihak pengusaha dalam menentukan kebijakan, perjanjian yang dibuat secara lisan menempatkan pihak pekerja borongan dalam posisi yang lemah. Dalam upaya perlindungan hukum terhadap para pekerja juga tidak sesuai dengan peraturan perundang-undangan yang berlaku.
\end{abstract}

\section{Keywords: Perlindungan, Hukum, Tenaga Kerja}

\section{PENDAHULUAN}

Pekerja borongan bekerja berdasarkan Perjanjian Kerja Waktu Tertentu (PKWT). Jenis perjanjian kerja tersebut mensyaratkan pembuatan perjanjian kerja secara tertulis dan jangka waktu kerjanya yang dibatasi oleh ketentuan peraturan perundang-undangan. Pada kenyataannya selama ini, di lapangan terdapat praktek dalam mempekerjakan pekerja borongan belum sesuai dengan ketentuan peraturan perundang-undangan. Pada praktek di lapangan banyak dijumpai pekerja boronganyang bekerja dengan perjanjian kerja secara lisan, yang kemudian hak dan kewajiban kedua pihak hanya disampaikan secara langsung tanpa adanya bukti tertulis.

Perlindungan hukum terhadap pekerja merupakan pemenuhan hak dasar yang melekat dan dilindungi oleh konstitusi sebagaimana yang diatur di dalam Pasal 27 ayat (2) UUD 1945 "Tiap-tiap warga Negara berhak atas pekerjaan dan penghidupan yang layak bagi kemanusiaan", dan Pasal 33 ayat (1) yang menyatakan bahwa "Perekonomian disusun sebagai usaha bersama atas kekeluargaan". ${ }^{1}$

Pelanggaran terhadap hak dasar yang dilindungi konstitusi merupakan pelanggaran hak asasi manusia. Perlindungan terhadap tenaga kerja dimaksudkan untuk menjamin hak-hak dasar pekerja dan menjamin kesamaan serta perlakuan tanpa diskriminasi atas dasar apapun untuk mewujudkan kesejahteraan pekerja dan keluarganya

\footnotetext{
${ }^{1}$ Undang-Undang Nomor 13 Tahun 2003Tentang Ketenagakerjaan
} 
dengan tetap memperhatikan perkembangan kemajuan dunia usaha dan kepentingan pengusaha. Peraturan perundang-undangan yang terkait dengan perlindungan bagi pekerja Undang-Undang No. 13 Tahun 2003 Tentang Ketenagakerjaan dan Peraturan Pelaksana dari perundang-undangan di bidang Ketenagakerjaan.

Tenaga kerja merupakan sumber daya manusia sebagai modal utama serta pelaksanaan dari pembangunan masyarakat pancasila, oleh karena itu, tenaga kerja sebagai pelaksana pembangunan harus di jamin haknya, diatur kewajibannya dan dikembangkan daya gunanya selain itu dalam pembangunan nasional yang semakin meningkat, dengan resiko dan tanggung jawab serta tantangan yang dihadapi perlu untuk diberikan perlindungan, pemeliharaan UndangUndang Nomor 13 Tahun 2003 tentang Ketenagakerjaan dan peningkatan kesejahteraan, sehingga menimbulkan rasa aman dalam bekerja. ${ }^{2}$

Perlindungan hukum terhadap pekerja selama ini masih dianggap sebagai beban biaya, sehingga beberapa perusahaan menggunakan alat pelindung diri yang tidak memenuh standar.Hal itu semakin diperparah dengan adanya alat pelindung diri palsu. Menurut data dari BPJS Ketenagakerjaan, menyebutkan bahwa terdapat 101.367 kasus di 17.069 perusahaan dari 359.734 perusahaan yang terdaftar dengan korban meninggal dunia sebanyak 2.382 orang sampai dengan bulan November tahun 2016. Angka kecelakaan kerja dan penyakit akibat kerja di Indonesia dirasa masih cukup tinggi.Salah satu penyebabnya adalah masih rendahnya perlindungan hukum terhadap tenaga kerja.

\section{Tenaga Pekerja}

\section{LANDASAN TEORI}

2 Soedarjadi, 2008, Hukum Ketenagakerjaan Di Indonesia, (Yogyakarta : Pustaka Yustisia), hal. 5
Tenaga kerja merupakan penduduk yang berada dalam usia kerja. Menurut Undang - Undang Nomor 13 tahun 2003 Bab I pasal 1 ayat 2 disebutkan bahwa tenaga kerja adalah setiap orang yang mampu melakukan pekerjaan guna menghasilkan barang dan atau jasa baik untuk memenuhi kebutuhan sendiri maupun untuk masyarakat .

Menurut DR Payaman Siamanjuntak tenaga kerja adalah penduduk yang sudah atau sedang bekerja, yang sedang mencari pekerjaan, dan yang melaksanakan kegiatan lain seperti bersekolah dan mengurus rumah tangga. Secara praksis pengertian tenaga kerja dan bukan tenaga kerja menurut dia hanya dibedakan oleh batas umur. $^{3}$

Jadi yang dimaksud dengan tenaga kerja yaitu individu yang sedang mencari atau sudah melakukan pekerjaan yang menghasilkan barang atau jasa yang sudah memenuhi persyaratan ataupun batasan usia yang telah ditetapkan oleh UndangUndang yang bertujuan untuk memperoleh hasil atau upah untuk kebutuhan hidup sehari-hari.

1. Klasifikasi Tenaga Kerja

Klasifikasi adalah penyusunan bersistem atau berkelompok menurut standar yang di tentukan. ${ }^{4}$ Maka, klasifikasi tenaga kerja adalah pengelompokan akan ketenaga kerjaan yang sudah tersusun berdasarkan kriteria yang sudah di tentukan yaitu :

a. Berdasarkan Penduduknya

1) Menurut Undang-Undang Tenaga Kerja, mereka yang dikelompokkan sebagai tenaga kerja yaitu mereka yang berusia antara 15 tahun sampai dengan 64 tahun.

2) Menurut Undang-Undang Tenaga Kerja Nomor 13 Tahun 2003, mereka adalah penduduk di luar usia, yaitu mereka yang

\footnotetext{
${ }^{3}$ Sendjun H Manululang, 1998, Pokok-Pokok Hukum Ketenagakerjaan Di Indonesia. ${ }^{4}$ Pius Partanto, 2001, Kamus Ilmiah Popular. Surabaya : Arkola, hal. 345.
} 
berusia di bawah 15 tahun dan berusia di atas 64 tahun.

b. Berdasarkan Batas Kerja

1) Angkatan kerja adalah penduduk usia produktif yang berusia 15-64 tahun yang sudah mempunyai pekerjaan tetapi sementara tidak bekerja, maupun yang sedang aktif mencari pekerjaan.

2) Bukan angkatan kerja adalah mereka yang berumur 10 tahun ke atas yang kegiatannya hanya bersekolah, mengurus rumah tangga dan sebagainya.

c. Berdasarkan Kualitasnya

1) Tenaga kerja terdidik adalah tenaga kerja yang memiliki suatu keahlian atau kemahiran dalam bidang tertentu dengan cara sekolah atau pendidikan formal dan nonformal.

2) Tenaga kerja terlatih Tenaga kerja terlatih adalah tenaga kerjayang memiliki keahlian dalam bidang tertentu dengan melalui pengalaman kerja. Tenaga kerja terampil ini dibutuhkan latihan secara berulang-ulang sehingga mampu menguasai pekerjaan tersebut.

3) Tenaga kerja tidak terdidik dan tidak terlatih Tenaga kerja tidak terdidik dan tidak terlatih adalah tenaga kerja kasar yang hanya mengandalkan tenaga saja. ${ }^{5}$ Salah satu masalah mendasar yang dihadapai Indonesia disepanjang perjalanan menjadi bangsa yang merdeka adalah masalah pengangguran, dimana pemerintah dengan berbagai upaya yang telah dilakukan untuk mengurangi akan tingkat pengangguran. Namun pada kenyataanya masalah ketenagakerjaan di Indonesia

\footnotetext{
${ }^{5}$ Dwiyanto Agus, 2006, Reformasi Birokrasi Publik di Indonesia, Yogyakarta : Gadjah Mada University Press. hal. 45.
}

masih banyak yang belum bisa diatasi oleh pemerintah.

\section{Hubungan Kerja}

Definisi hubungan Kerja Menurut Hartono Widodo dan Judiantoro, hubungan kerja adalah kegiatan pengerahan tenaga/jasa seseorang secara teratur demi kepentingan orang lain yang memerintahnya (pengusaha/majikan) sesuai dengan perjanjian kerja yang telah disepakati. ${ }^{6}$

Hubungan kerja pada dasarnya meliputi hal-hal mengenai:

1. Pembuatan Perjanjian Kerja (merupakan titik tolak adanya suatu hubungan kerja).

2. Kewajiban Pekerja (yaitu melakukan pekerjaan, sekaligus merupakan hak dari pengusaha atas pekerjaan tersebut).

3. Kewajiban Pengusaha (yaitu membayar upah kepada pekerja, sekaligus merupakan hak dari si pekerja atas upah)

a. Berakhirnya Hubungan Kerja

1) Cara Penyelesaian Perselisihan antara pihak-pihak yang bersangkutan. $^{7}$

Dengan terwujudnya hubungan kerja, maka baik pengusaha maupun pekerja yang bersangkutan masing-masing telah terikat oleh isi perjanjian tersebut dan masing-masing telah memperoleh hak, dimana pengusaha berhak memerintah dan menugaskan pekerja agar bekerja dengan giat dan rajin tanpa melampaui batas-batas isi perjanjian kerja, dan pekerja berhak menerima upah dan jaminan-jaminan lainnya yang diberikan pengusaha tanpa

\footnotetext{
${ }^{6}$ Hartono, Judiantoro, Segi Hukum

Penyelesaian Perselisihan Perburuhan, (Jakarta: Rajawali Pers, 1992), hal. 10.)

${ }^{7}$ Tjepi F. Aloewic, Naskah Akademis Tentang

Pemutusan Hubungan Kerja dan Penyelesaian Perselisihan Industrial, Cetakan ke-11, (Jakarta: BPHN, 1996), hal. 32.
} 
melampaui pula batas-batas isi perjanjian kerja. ${ }^{8}$

Bentuk jaminan yang dimaksud yaitu jaminan sosial tenaga kerja. Undang-Undang Nomor 13 Tahun 2003 tentang Ketenagakerjaan pada Pasal 99 menyebutkan bahwa setiap pekerja berhak atas jaminan sosial tenaga kerja. Jaminan tersebut diantaranya meliputi jaminan kecelakaan kerja, jaminan kematian, dan jaminan pemelihaan kesehatan.

Suasana kerja dan lingkungan kerja yang baik sangat diharapkan dalam jalinan hubungan kerja, dapat diciptakan melalui:

b. Adanya syarat-syarat kerja yang baik,

1) Hubungan antara pengusaha dengan stafnya dan para pekerja baik atasan maupaun bawahan yang harmonis, sehingga antara masing-masing selalu timbul toleransi

2) Hubungan antara pekerja dengan sesama pekerja lainnya, dan

c. Keadaan perusahaan dan usahanya. $^{9}$

Dalam hal perusahaan membuka kesempatan kerja, tentunya para pekerja yang ingin mengisinya akan selalu lebih daripada apa yang ditawarkan. Sudah selayaknya pengusaha melakukan tindakantindakan yang bijaksana sebagai berikut.

1) Penerimaan pekerja harus terbuka bagi setiap warga masyarakat yang dapat memenuhi syarat-syarat pendidikan, pengalaman kerja, kemampuan dan kecakapan untuk menjalankan tugas

${ }^{8}$ G. Kartasapoetra, dkk, Hukum Perburuhan di Indonesia Berlandaskan Pancasila, Jakarta, Sinar Grafika, 1994, hlm. 18.

${ }^{9}$ G. Kartasapoetra, dkk, op.cit, hlm. 30. pekerjaan tersebut, tanpa membeda-bedakan golongan, ketentuan dan agama,

2) Dalam pelaksanaan perekrutan para pekerja tersebut, sudah sepatutnya pihak pengusaha mengutamakan jalan yang harus ditempuh, yaitu dengan melalui Kantor Departemen Tenaga Kerja setempat bidang Penyediaaan dan Penggunaan Tenaga Kerja yang daripadanya pengusaha akan memperoleh pengiriman-pengiriman pekerja yang dibutuhkan dimana segala persyaratan yang diperlukan telah terpenuhi,

3) Para pekerja yang berhasil dapat diterima mengisi kesempatan kerja itu, harus diperlakukan sesuai dengan ketentuanketentuan hukum dan perundangundangan yang berlaku, dan

4) Para pekerja yang diterima, akan memperoleh sejumlah upah yang sesuai dengan kelayakan dan atau ketentuan umum yang berlaku, sesuai tugas kerja yang dijalankannya.

Dengan diwujudkannya syarat-syarat kerja yang sesuai ketentuan atau perundang-undangan yang berlaku, syarat-syarat kerja dan peraturan kerja akan diterima dengan baik oleh pekerja dengan senang hati. Bekerja dengan senang akan mewujudkan produktivitas kerja yang tinggi, sehingga produksi akan meningkat kuantitas dan kualitasnya, sedang bagi pekerja yang tidak dikerjakan di lapangan produksi akan selalu mewujudkan dedikasi yang tinggi sehingga segala tugas pekerjaan tersebut dapat diselesaikan tepat waktunya dengan penuh tanggung jawab dan penuh keberhasilan sangat memuaskan. ${ }^{10}$ 
Hubungan kerja menurut Undang-Undang Nomor 13 Tahun 2003 sebagaimana yang terdapat dalam Pasal 1 angka 15 adalah hubungan antara pengusaha dengan pekerja berdasarkan perjanjian kerja, yang mempunyai unsur pekerja, upah, dan perintah. ${ }^{11}$

\section{Perlindungan Hukum Terhadap Tenaga Kerja}

Secara yuridis Pasal 5 UndangUndang Nomor 13 Tahun 2003 tentang Ketenagakerjaan memberikan perlindungan bahwa setiap tenaga kerja berhak dan mempunyai kesempatan yang sama untuk memperoleh pekerjaan dan penghidupan yang layak tanpa membedakan jenis kelamin, suku, ras, agama, dan aliran politik sesuai dengan minat dan kemampuan tenaga kerja yang bersangkutan, termasuk perlakuan yang sama terhadap para penyandang cacat. Sedangkan Pasal 6 mewajibkan kepada pengusaha untuk memberikan hak dan kewajiban pekerja/buruh tanpa membedakan jenis kelamin, suku, ras, agama, warna kulit, dan aliran politik.

Perlindungan tenaga kerja dapat diklasifikasikan menjadi tiga macam.

1. Perlindungan secara ekonomis, yaitu perlindungan pekerja dalam bentuk penghasilan yang cukup, termasuk bila tenaga kerja tidak bekerja diluar kehendaknya.

2. Perlindungan sosial, yaitu perlindungan tenaga kerja dalam bentuk jaminan kesehatan kerja, dan kebebasan berserikat dan perlindungan hak untuk berorganisasi.

3. Perlindungan teknis, yaitu perlindungan tenaga kerja dalam bentuk keamanan dan keselamatan.

Selain perlindungan tenaga kerja di atas, terdapat perlindungan lain terhadap pekerja yaitu:

1. Norma Keselamatan Kerja, meliputi keselamatan kerja yang bertalian

${ }^{11}$ Pasal 1 angka 15 Undang-Undang Nomor 13 Tahun 2003 tentang Ketenagakerjaan. dengan mesin, alat-alat kerja bahan dan proses pengerjaan, keadaan tempat kerja, lingkungan serta cara melakukan pekerjaan.

2. Norma kesehatan kerja dan higiene kesehatan perusahaan, yang meliputi pemeliharaan dan peningkatan keselamatan pekerja, penyediaan perawatan medis bagi pekerja, dan penetapan standar kesehatan kerja.

3. Norma kerja, berupa perlindungan hak tenaga kerja secara umum baik sistem pengupahan, cuti, kesusilaan, dan religius dalam rangka memelihara kinerja pekerja.

4. Norma kecelakaan kerja, berupa pemberian ganti rugi perawatan atau rehabilitasi akibat kecelakaan kerja dan/atau menderita penyakit akibat pekerjaan, dalam hal ini ahli waris berhak untuk menerima ganti rugi.

Selain perlindungan terhadap pekerjanya, terdapat jenis perlindungan lain, yaitu:

1. Program Jaminan Sosial Tenaga Kerja (JAMSOSTEK)

Program

Jamsostek pengaturannya diatur dalam UndangUndang Nomor 3 Tahun 1992 yang menurut Pasal 1 ayat (1) Jamsostek adalah suatu perlindungan bagi tenaga kerja dalam bentuk santunan berupa uang sebagai pengganti sebagian dari penghasilan yang hilang atau berkurang dan pelayanan sebagai akibat peristiwa atau keadaan yang dialami oleh tenaga kerja berupa kecelakaan kerja, sakit, hamil, bersalin, hari tua dan meninggal dunia. Program Jamsostek merupakan kelanjutan program Asuransi Sosial Tenaga Kerja (ASTEK) yang didirikan menurut Peraturan Pemerintah Nomor 33 Tahun 1977.

2. Perlindungan keselamatan dan kesehatan

Perlindungan keselamatan dan kesehatan terhadap tenaga kerja diatur dalam Pasal 86 ayat (1) UndangUndang Nomor 13 Tahun 2003 tentang ketenagakerjaan disebutkan bahwa setiap pekerja/buruh mempunyai hak 
untuk memperoleh perlindungan atas keselamatan dan kesehatan kerja, moral, dan kesusilaan, serta perlakuan yang sesuai dengan harkat dan martabat manusia serta nilai-nilai agama.

3. Perlindungan upah

Perlindungan upah merupakan aspek perlindungan yang paling penting bagi tenaga kerja. Bentuk perlindungan pengupahan merupakan tujuan dari pekerja/buruh dalam melakukan pekerjaan untuk mendapatkan penghasilan yang cukup untuk membiayai kehidupannya bersama dengan keluarganya, yaitu penghidupan yang layak bagi kemanusiaan. Selama pekerja/buruh melakukan pekerjaannya, ia berhak atas pengupahan yang menjamin kehidupannya bersama dengan keluarganya.

\section{Hak-Hak Pekerja}

Hak dasar pekerja merupakan hak yang melekat sejak dia diangkat sebagai karyawan dalam sebuah perusahaan. Hak ini meliputi keselamatan dan kesehatan kerja sampai dengan kesempatan untuk berkembang di perusahaan tersebut. Berikut ini ulasan 8 hak dasar pekerja dan aturan yang mengaturnya:

1. Hak untuk Mengembangkan Potensi Kerja, Mengembangkan Minat, Bakat dan Kemampuan

Hak dasar yang pertama ini diatur dalam Undang Undang Nomor 21 tahun 2000 dan UU 12/2003, yang menyatakan bahwa setiap Pekerja memiliki hak untuk mengembangkan potensi kerja, serta memperoleh kesempatan untuk mengembangkan minat, bakat dan kemampuan. Undangundang ini juga mengatur bahwa seorang Pekerja mempunyai hak untuk terlindungi dari tindak kesusilaan dan moral, kesehatan dan keselamatan kerja, serta perlakuan yang sesuai dengan harkat dan martabat sebagai Manusia dan nilai-nilai Agama.

2. Hak Dasar atas Jaminan Sosial, Kesehatan dan Keselamatan Kerja
Hak ini diatur dalam Peraturan Menteri (Permen) Nomor 4/1993, Peraturan Menteri No 1/1998, Keputusan Presiden Nomor 22/1993, Peraturan Pemerintah Nomor 14/1993, Undang-Undang Nomor 1/1970, UU 3/1992, serta UU 13/2003. Hak dasar yang dimaksud termasuk didalamnya hak untuk memperoleh jaminan pemeliharaan kesehatan, jaminan hari tua, jaminan kematian, dan jaminan kecelakaan kerja.

3. Setiap Pekerja berhak Mendapatkan Upah yang Layak.

Hak dasar ini diatur dalam Peraturan Menteri (Permen) Nomor 1/1999, PP 8/1981, serta UU 13/2003 dikatakan, seorang Pekerja memiliki hak untuk mendapatkan upah yang layak. pemilik modal atau pihak Perusahaan juga diwajibkan mengikuti ketentuan upah minimum yang berlaku di kabupaten/kota/kawasan tersebut. Perusahaan juga diwajibkan untuk meninjau besaran upah ketika Pekerja sudah bekerja selama lebih dari satu tahun, dan tidak boleh diskriminatif terhadap Pekerja Perempuan dan Pekerja Laki-laki.

4. Hak Dasar untuk Berlibur, Cuti, Istirahat, serta Memperoleh Pembatasan Waktu Kerja.

Hal ini diatur dalam UndangUndang Nomor 13 tahun 2003 yang menyebutkan bahwa perusahaan diwajibkan untuk memberikan kompensasi jika karyawan bekerja di luar jam kerja dengan memberikan kompensasi upah lembur. Di samping itu, seorang Pekerja juga mendapatkan hak untuk menunaikan ritual keagamaan menurut tata cara tertentu yang diatur oleh Agama yang dianutnya.

5. Hak Dasar untuk Membentuk Serikat Pekerja.

Hak-hak dasar ini diatur oleh Undang-Undang Nomor 21 tahun 2000, dan Undang-Undang Nomor 13 tahun 2003. Hal ini dimaksudkan sebagai 
media penyalur aspirasi Pekerja yang memiliki kapasitas hukum untuk membuat perjanjian kerja dengan pemilik modal atau pihak Perusahaan. Perjanjian kerja yang disepakati bersama harus mencakup dengan hak dan kewajiban Buruh maupun serikatnya, hak dan kewajiban Pengusaha, jangka waktu berlakunya perjanjian, serta tandatangan dari pihakpihak terkait yang terlibat.

6. Hak untuk Melakukan Aksi Mogok Kerja.

Hak ini diatur dalam keputusan Menteri Nomor 232 tahun 2003, dan Undang Undang Nomor 13 tahun 2003. Aksi mogok kerja tersebut harus dilakukan sesuai prosedur, yang mana para Pekerja haru menginformasikan ihwal itu sekurangnya 7 hari sebelum berlangsung.

7. Hak Dasar Khusus Terkait Persoalan Jam Kerja untuk Pekerja Perempuan.

Hal ini diatur dalam Keputusan Menteri Nomor 224 tahun 2003, dan Undang Undang Nomor 13 tahun 2003. Pemerintah melarang pihak Perusahaan mempekerjakan Karyawan Perempuan antara jam 23.00 WIB sampai jam 7.00 WIB, atau yang lebih dikenal dengan istilah shift 3. Aturan ini berlaku untuk Pekerja Perempuan yang umurnya kurang dari 18 tahun.

8. Hak Perlindungan atas Pemutusan Hubungan Kerja.

Namun bila hal tersebut tidak dapat dihindari, maka perundingan wajib dilakukan oleh kedua belah pihak terkait, yakni Buruh dan pihak Pengusaha atau perwakilan Perusahaan. Jika jalur perundingan tidak menemukan titik terang atau jalan keluar, maka pihak Perusahaan bisa memutuskan hubungan kerja setelah ditetapkan secara sah dan resmi oleh Lembaga yang berwenang.Seorang Pekerja tidak boleh di PHK jika berhalangan sakit sesuai dengan keterangan dokter, atau jika Pekerja tengah menjalankan kewajiban Negara, atau tengah menjalankan ibadah keagamaan, menikah, dan hamil.

III. METODE PENELITIAN

Metode penelitian pada dasarnya merupakan cara ilmiah untuk mendapatkan data dengan tujuan dan kegunaan tertentu. Guna memperoleh data yang dapat menunjang validitas penelitian, maka diperlukanaanya metode penelitian, yaitu langkah-langkah operasional yang harus dilakukan dalam setiap penelitian, sehingga tujuan penelitian mendapatkan kebenaran objektif dan bersifat ilmiah dapat terwujud.

\section{Jenis Penelitian}

Metode penulisan yang digunakan dalam penulisan skripsi ini adalah metode normatif yaitu penelitian hukum kepustakaan yang mengacu kepada normanorma yang trdapat dalam peraturan perundang-undangan, pendapat para ahli hukum yang dituangkan dalam karangan buku dan putusan pengadilan. Dipilihnya jenis penelitian normatif karena penelitian ini menguraikan permasalahanpermasalahan yang ada dan selanjutnya di bahas dengan kajian yang berdasarkan teori-teori hukum kemudian dikaitkan dengan peraturan perundang-undangan yang berlaku dalam praktek hukum.

\section{Teknik Pengumpulan Bahan Hukum}

Bahan hukum primer dan bahan hukum sekunder dikumpulkan melalui studi pustaka (library research), yaitu menginventarisasi bahan-bahan yang relavan dengan pokok yang sedang di bahas. Selanjutnya bahan-bahan hukum tersebut dicatat bagian penting dan di kumpulkan, kemudian dilakukan pengolahan dengan jalan mengklasifikasian bahan-bahan yang ada sesuai dengan urutan dan rumusan masalah yang diteliti dalam skripsi ini.

\section{Teknik Analisis Bahan Hukum}

Penelitian ini digunakan teknik kualitatif atau yang juga sering di kenal dengan analisis deskriptif kualitatif maka keseluruhan data yang terkumpul, baik dari data primer maupun sekunder serta bahan hukum penunjang akan diolah dengan 
dianalisis dengan cara menyusun data secara sistem. Pengelolahan data yang dilakukan penulis adalah dengan mengkaitkan hasil sebuah wawancara dengan dasar-dasar hukum yang berlaku baik Undang-Undang Dasar Negara Republik Indonesia Tahun 1945, peraturan perundang-undangan, peraturan daerah, serta dari kajian perpustakaan berupa literature maupun artikel dan selanjutnya dirangkum dalam suatu wadah berupa penelitian untuk sebuah kejelasan dari sebuah asumsi-asumsi dan isu-isu hukum yang ada di dalam masyarakat.

\section{HASIL DAN PEMBAHASAN}

Perlindungan Hukum Bagi Pekerja Berdasarkan Perundang-Undangan Yang Berlaku

Jaminan perlindungan hukum terhadap pemborong/pekerja diatur dalam Undang-Undang No.13 Tahun 2003 tentang Ketenagakerjaan, sebagai berikut :

1. Penyandang Cacat

Didalam masalah perlindungan terhadap pekerja/buruh, yang perlu diperhatikan secara tersendiri adalah penyandang cacat. Di dalam Pasal 67 Undang-Undang No. 13 Tahun 2003 mengatur soal penyandang cacat yang intinya bahwa pengusaha dapat memberikan pekerjaan penyandang cacat dengan memperhatikan atau mematuhi aturan sebagai berikut:

a. Pengusaha yang mempekerjakan tenaga kerja penyandang cacat wajib memberikan perlindungan sesuai dengan jenis dan derajat kecacatannya.

b. Pemberian perlindungan sebagaimana dimaksud pada ayat (1) dilaksanakan sesuai dengan peraturan perundang-undangan yang berlaku.

2. Pekerja Anak

Bagi pekerja anak diatur dalam Pasal $68,69,70,71,72,73,74$ dan 75 Undang-Undang No.13 Tahun 2003 yang menyatakan bahwa:

Dalam Pasal 68 Undang-Undang Nomor 13 Tahun 2003 tentang
Ketenagakerjaan menjelaskan bahwa Pengusaha dilarang mempekerjakan anak. Menurut Pasal 69 ayat (1) Undang-Undang Nomor 13 Tahun 2003 tentang Ketenagakerjaan menjelaskan bahwaketentuan sebagaimana dimaksud dalam Pasal 68 dapat dikecualikan bagi anak berumur antara 13 (tiga belas) tahun sampai dengan 15 (lima belas) tahun untuk melakukan pekerjaan ringan sepanjang tidak mengganggu perkembangan dan kesehatan fisik, mental, dan sosial.Selanjutnya pasal 69 ayat (2) bahwa Pengusaha yang mempekerjakan anak pada pekerjaan ringan sebagaimana dimaksud pada ayat (1) harus memenuhi persyaratan:

a. izin tertulis dari orang tua atau wali;

b. perjanjian kerja antara pengusaha dengan orang tua atau wali;

c. waktu kerja maksimum 3 (tiga) jam;

d. dilakukan pada siang hari dan tidak mengganggu waktu sekolah;

e. keselamatan dan kesehatan kerja;

f. adanya hubungan kerja yang jelas; dan

g. menerima upah sesuai dengan ketentuan yang berlaku.

Pada pasal 69 ayat (3) yaitu ketentuan sebagaimana dimaksud pada ayat (2) huruf a, b, f dan g dikecualikan bagi anak yang bekerja pada usaha keluarganya.

Pada Pasal 70 ayat (1) UndangUndang Nomor 13 Tahun 2003 tentang Ketenagakerjaan menjelaskan bahwa Anak dapat melakukan pekerjaan di tempat kerja yang merupakan bagian dari kurikulum pendidikan atau pelatihan yang disahkan oleh pejabat yang berwenang.Selanjutnya pasal 70 ayat (2) Anak sebagaimana dimaksud pada ayat (1) paling sedikit berumur 14 (empat belas) tahun.Pasal 70 ayat (3) Pekerjaan sebagaimana dimaksud pada ayat (1) dapat dilakukan dengan syarat: 
a. diberi petunjuk yang jelas tentang cara pelaksanaan pekerjaan serta bimbingan dan pengawasan dalam melaksanakan pekerjaan; dan

b. diberi perlindungan keselamatan dan kesehatan kerja.

Pada Pasal 71 ayat (1) Undang-Undang Nomor 13 Tahun 2003 tentang Ketenagakerjaan bahwa Anak dapat melakukan pekerjaan untuk mengembangkan bakat dan minatnya.Selanjutnya menurut pasal 71 ayat (2) Pengusaha yang mempekerjakan anak sebagaimana dimaksud pada ayat (1) wajib memenuhi syarat:

a. di bawah pengawasan langsung dari orang tua atau wali;

b. waktu kerja paling lama 3 (tiga) jam sehari; dan

c. kondisi dan lingkungan kerja tidak mengganggu perkembangan fisik, mental, sosial, dan waktu sekolah.

Pada ayat (3) Ketentuan mengenai anak yang bekerja untuk mengembangkan bakat dan minat sebagaimana dimaksud pada ayat (1) dan ayat (2) diatur dengan Keputusan Menteri.Menurut Pasal 72 ayat (1) Undang-Undang Nomor 13 Tahun 2003 tentang Ketenagakerjaan bahwaDalam hal anak dipekerjakan bersama-sama dengan pekerja/buruh dewasa, maka tempat kerja anak harus dipisahkan dari tempat kerja pekerja/buruh dewasa.Pada Pasal 73 ayat (1) UndangUndang Nomor 13 Tahun 2003 tentang Kewarganegaraan bahwa Anak dianggap bekerja bilamana berada di tempat kerja, kecuali dapat dibuktikan sebaliknya.Pada Pasal 74 ayat (1) Menjelaskan bahwa Siapapun dilarang mempekerjakan dan melibatkan anak pada pekerjaan-pekerjaan yang terburuk.Pasal 74 ayat (2) Pekerjaanpekerjaan yang terburuk yang dimaksud pada ayat (1) meliputi:

a. segala pekerjaan dalam bentuk perbudakan atau sejenisnya; b. segala pekerjaan yang memanfaatkan, menyediakan, atau menawarkan anak untuk pelacuran, produksi pornografi, pertunjukan porno, atau perjudian;

c. segala pekerjaan yang memanfaatkan, menyediakan, atau melibatkan anak untuk produksi dan perdagangan minuman keras, narkotika, psikotropika, dan zat adiktif lainnya; dan/atau

d. semua pekerjaan yang membahayakan kesehatan, keselamatan, atau moral anak.

Pasal 74 ayat (3) Jenis-jenis pekerjaaan yang membahayakan kesehatan, keselamatan, atau moral anak sebagaimana dimaksud pada ayat (2) huruf d ditetapkan dengan Keputusan Menteri.Menurut Pasal 75 ayat (1) Undang-Undang Nomor 13 tahun 2003 tentang Ketenagakerjaan bahwa Pemerintah berkewajiban melakukan upaya penanggulangan anak yang bekerja di luar hubungan kerja. Pasal 75 ayat (2) Upaya penanggulangan sebagaimana dimaksud pada ayat (1) diatur dengan Peraturan Pemerintah.

3. Pekerja/BuruhPerempuan Mengenai pekerja/buruh perempuan diatur dalam Pasal 76 Undang-Undang No. 13 Tahun 2003, sebagai berikut:Pada Pasal 76 ayat (1) Undang-Undang Nomor 13 tahun 2003 tentang Ketenagakerjaan menerangkan bahwa Pekerja/buruh perempuan yang berumur kurang dari 18 (delapan belas) tahun dilarang dipekerjakan antara pukul 23.00 s.d. 07.00.Selanjutnya pasal 76 ayat (2) Pengusaha dilarang mempekerjakan pekerja/buruh perempuan hamil yang menurut keterangan dokter berbahaya bagi kesehatan dan keselamatan kandungannya maupun dirinya apabila bekerja antara pukul 23.00 s.d. pukul 07.00.pada pasal 76 ayat (3) Pengusaha yang mempekerjakan pekerja/buruh 
perempuan antara pukul 23.00 s.d. pukul 07.00 wajib:

a. memberikan makanan dan minuman bergizi; dan

b. menjaga kesusilaan dan keamanan selama di tempat kerja.

Pada pasal 76 ayat (4) Pengusaha wajib menyediakan angkutan antar jemput bagi pekerja/buruh perempuan yang berangkat dan pulang bekerja antara pukul 23.00 s.d. pukul 05.00.Pasal 76 ayat (5) Ketentuan sebagaimana dimaksud pada ayat (3) dan ayat (4) diatur dengan Keputusan Menteri.

Perlindungan hukum berarti membahas hak dan kewajiban. Berkaitan dengan pemborong berarti berbicara tentang hak-hak para pekerja setelah melakukan kewajibannya. Keberadaan pekerja atau pemborong sangat dibutuhkan untuk mengerjakan sebuah pembangunan kontruksi proyek. Pengerjaan sebuah bangunan yang ada di kawasan Kuta Selatan khususnya Villa Permata Ariza sangat membawa keuntungan diantaranya membantu pemerintah dalam upaya mengurangi pengangguran dengan tersedianya lapangan kerja dan membantu warga sekitar wilayah tersebut untuk mendapatkan sebuah pekerjaan walaupun tidak tetap.Namun perlu diketahui kehidupan para pekerja dalam sebuah pekerjaan khususnya pemborongbelum mendapatkan perlakuan sebagaimana ketentuan dalam peraturan ketenagakerjaan.

Berdasarkan hasil observasi peneliti yang berhasil diperoleh di lapangan pelaksanaan perlindungan hukum terhadap pekerja borongan dalam pembangunan sebuah proyek meliputi sebagai berikut :

4. Perjanjian Kerja

Perjanjian kerja merupakan perjanjian antara pekerja/buruh yang berisi suatu hubungan kerja yang dibuat atas kesepakatan kedua belah pihak. Perjanjian kerja di atur dalam pasal
116, 117 sampai 132 Undang-Undang Nomor 13 Tahun 2003 tentang Ketenagakerjaan, maka Perjanjian yang dimaksud dalam undang-undang adalah sebagai berikut :

Pada Pasal 116 ayat 1 UndangUndang Nomor 13 tahun 2003 tentang Ketenagakerjaan menjelaskan bahwa perjanjian kerja bersama dibuat oleh serikat pekerja/serikat buruh atau beberapa serikat pekerja/serikat buruh yang telah tercatat pada instansi yang bertanggung jawab di bidang ketenagakerjaan dengan pengusaha atau beberapa pengusaha. Selanjutnya pasal 116 ayat (2) Penyusunan perjanjian kerja bersama sebagaimana dimaksud pada ayat (1) dilaksanakan secara musyawarah. Pada pasal 116 ayat (3) Perjanjian kerja bersama sebagaimana dimaksud pada ayat (1) harus dibuat secara tertulis dengan huruf latin dan menggunakan bahasa Indonesia. dan pasal 116 ayat (4) Dalam hal terdapat perjanjian kerja bersama yang dibuat tidak menggunakan bahasa Indonesia, maka perjanjian kerja bersama tersebut harus diterjemahkan dalam bahasa Indonesia oleh penerjemah tersumpah dan terjemahan tersebut dianggap sudah memenuhi ketentuan sebagaimana dimaksud pada ayat (3).Pada Pasal 117 Undang-Undang Nomor 13 tahun 2003 tentang Ketenagakerjaan menjelaskan bahwa dalam hal musyawarah sebagaimana dimaksud dalam pasal 116 ayat (2) tidak mencapai kesepakatan, maka penyelesaiannya dilakukan melalui prosedur penyelesaian perselisihan hubungan industrial.

5. Pengupahan

Pada pasal 1 angka 30 UndangUndang Nomor 13 Tahun 2003 tentang Ketenagakerjaan upah adalah hak pekerja/buruh yang diterima dan dinyatakan dalam bentuk uang sebagai imbalan dari pengusaha atau pemberi kerja kepada pekerja/buruh yang ditetapkan, atau peraturan perundangundangan, termasuk tunjangan bagi 
pekerja/buruh dan keluarganya atas suatu pekerjaan dan jasa yang telah atau akan dilakukan.

Pada pasal 88 ayat (1) UndangUndang Nomor 13 Tahun 2003 tentang Ketenagakerjaan bahwa setiap pekerja/buruh berhak memperoleh penghasilan yang memenuhi penghidupan yang layak bagi kemanusiaan. Selanjutnya menurut pasal 88 ayat (2) menjelaskan bahwa untuk mewujudkan penghasilan yang memenuhi penghidupan yang layak bagi kemanusiaan sebagaimana dimaksud pada ayat (1), pemerintah menetapkan kebijakan pengupahan yang melindungi pekerja/buruh .

Pada pasal 89 ayat (1) UndangUndang Nomor 13 Tahun 2003 tentang Ketenagakerjaan menjelaskan bahwa upah minimum sebagaimana dimakud dapat pasal 88 ayat (3) huruf a dapat terdiri atas :

Upah minimum sebagaimana dimaksud dalam Pasal 88 ayat (3) huruf a dapat terdiri atas:

a. upah minimum berdasarkan wilayah provinsi atau kabupaten/kota;

b. upah minimum berdasarkan sektor pada wilayah provinsi atau kabupaten/kota;

Pasal 92 ayat (1) UndangUndang 13 Tahun 2003 tentang Ketenagakerjaan menjelaskan bahwa Pengusaha menyusun struktur dan skala upah dengan memperhatikan golongan, jabatan, masa kerja, pendidikan, dan kompetensi.Pada ayat (2) penambahan bahwa Pengusaha melakukan peninjauan upah secara berkala dengan memperhatikan kemampuan perusahaan dan produktivitas.Pasal 92 ayat (3) Undang-Undang 13 Tahun 2003 tentang Ketenagakerjaan menjelaskan bahwa Ketentuan mengenai struktur dan skala upah sebagaimana dimaksud pada ayat (1) diatur dengan Keputusan Menteri.Pasal 93 ayat (1) Undang-Undang 13 Tahun 2003 tentang Ketenagakerjaan menjelaskan bahwa Upah tidak dibayar apabila pekerja/buruh tidak melakukan pekerjaan.Ayat (2) menjelaskan bahwa Ketentuan sebagaimana dimaksud pada ayat (1) tidak berlaku, dan pengusaha wajib membayar upah apabila:

a. pekerja/buruh sakit termasuk pekerja/buruh perempuan yang sakit pada hari pertama dan kedua masa haidnya sehingga tidak dapat melakukan pekerjaan;

b. pekerja/buruh tidak masuk bekerja karena pekerja/buruh menikah, menikahkan, mengkhitankan, membaptiskan anaknya, isteri melahirkan atau keguguran kandungan, suami atau isteri atau anak atau menantu atau orang tua atau mertua atau anggota keluarga dalam satu rumah meninggal dunia;

c. pekerja/buruh tidak dapat melakukan pekerjaannya karena sedang menjalankan kewajiban terhadap negara;

d. pekerja/buruh tidak dapat melakukan pekerjaannya karena menjalankan ibadah yang diperintahkan agamanya;

e. pekerja/buruh bersedia melakukan pekerjaan yang telah dijanjikan tetapi pengusaha tidak mempekerjakannya, baik karena kesalahan sendiri maupun halangan yang seharusnya dapat dihindari pengusaha;

f. pekerja/buruh melaksanakan hak istirahat;

g. pekerja/buruh melaksanakan tugas serikat pekerja/serikat buruh atas persetujuan pengusaha; dan

h. pekerja/buruh melaksanakan tugas pendidikan dari perusahaan.

Pasal 93 ayat (3) Upah yang dibayarkan kepada pekerja/buruh yang sakit sebagaimana dimaksud pada ayat

(2) huruf a sebagai berikut:

a. untuk 4 (empat) bulan pertama, dibayar $100 \%$ (seratus perseratus) dari upah; 
b. untuk 4 (empat) bulan kedua, dibayar $75 \%$ (tujuh puluh lima perseratus) dari upah;

c. untuk 4 (empat) bulan ketiga, dibayar 50\% (lima puluh perseratus) dari upah; dan

d. untuk bulan selanjutnya dibayar $25 \%$ (dua puluh lima perseratus) dari upah sebelum pemutusan hubungan kerja dilakukan oleh pengusaha.

Pasal 93 ayat (4) Upah yang dibayarkan kepada pekerja/buruh yang tidak masuk bekerja sebagaimana dimaksud pada ayat (2) huruf b sebagai berikut:

a. pekerja/buruh menikah, dibayar untuk selama 3 (tiga) hari;

b. menikahkan anaknya, dibayar untuk selama 2 (dua) hari;

c. mengkhitankan anaknya, dibayar untuk selama 2 (dua) hari;

d. membaptiskan anaknya, dibayar untuk selama 2 (dua) hari;

e. isteri melahirkan atau keguguran kandungan, dibayar untuk selama 2 (dua) hari;

f. suami/isteri, orang tua/mertua atau anak atau menantu meninggal dunia, dibayar untuk selama 2 (dua) hari; dan

g. anggota keluarga dalam satu rumah meninggal dunia, dibayar untuk selama 1 (satu) hari.

Berdasarkan hasil observasi peneliti yang diperoleh di lapangan ada perjanjian kerja yang harus disepakati sebelum melakukan hubungan kerja dengan pemilik bangunan, perjanjian kerjayang telah disepakati yaitu perjanjian kerja yang dibuat secara lisan. Perjanjian kerja secara lisan diperbolehkan asalkan isi perjanjian kerja itu disepakati kedua belah pihak yaitu antara pemborong dengan pemilik bangunan. Dalam Perjanjian kerja yang disepakati secara lisan, isinya hanya mengenai upah dan tata tertib dalam bekerja. Perjanjian kerja berisi mengenai upah tiap harinya dan pihak pengusaha atau pemilik bangunan hanya memberikan pesan untuk berhatihati dalam melakukan pekerjaan. Isi dalam perjanjian kerja yang memuat kewajiban para pekerja/pemborong untuk melakukan pekerjaan sedangkan besarnya upah disesuaikan dengan standart UMK Kabupaten Badung dan pembayaran upah diberikan dalam sebulan dua kali. Bagi pemborong untuk bisa bekerja saja itu sudah beruntung daripada harus menganggur. Perjanjian kerja yang dibuat secara lisan mempunyai (konsekuensi) yang berbeda dengan perjanjian kerja yang dibuat secara tertulis. Dalam hal ini pemilik perusahaan menyalahi aturan karena tidak mematuhi pasal 116 ayat 1 UU Nomor 13 Tahun 2003 yang berbunyi "Perjanjian kerja bersama dibuat oleh serikat pekerja/serikat buruh atau beberapa serikat pekerja/serikat buruh yang telah tercatat pada instansi yang bertanggung jawab di bidang ketenagakerjaan dengan pengusaha atau beberapa pengusaha" Karena perjanjian kerja ini tidak dibuat secara tertulis sehingga apabila terjadi pelanggaran terhadap pemborong tidak dapat dijadikan sebagai alat bukti otentik. Pekerja dalam hubungan kerja tidak akan dipersulit asalkan bisa mematuhi aturan yang telah disepakati yaitu menjalankan pekerjaannya dengan sungguh sungguh, jujur, tekun, disiplin, tidak ceroboh, dan tidak ada kecurangan. Apabila ada pelanggaran maka akan diberi teguran terlebih dahulu oleh pemilik bangunan.

Berdasarkan isi dari perjanjian kerja antara pemborong dengan pemilik perusahaan, pemenuhan hak-hak pekerja seperti perlindungan upah dan kesejahteraan serta syarat kerja yang timbul tetap merupakan tanggung jawab dari pihak pemborong selaku penyedia jasa pekerja.Pekerja borongan disediakan mess (tempat tinggal sementara) oleh pemilih perusahaan yang berlokasi di Jalan Karang Mas 
Sejahtera berdekatan dengan lokasi pembangunan Villa tersebut. Untuk sistem pengupahan diberikan secara harian sebesar Rp. 80.000,00 yang sudah termasuk uang makan harian, dengan kurun waktu kerja dari pukul 08.00 WITA sampai dengan pukul 17.00 WITA, di potong waktu istirahat pukul 12.00 Wita sampai dengan pukul 13.00 WITA. Pekerjaan yang dilakukan sejak pukul 17.00 WITA sampai dengan pukul 22.00 WITA dianggap sebagai lembur dan mendapatkan upah dengan sistem per/jam yaitu sebesar Rp. 10.000,00. Para pekerja borongan sudah menyediakan alat pelindung diri sebagai salah satu syarat yang harus dipernuhi sebelum melakukan pekerjaan. Alat pelindung diri yang disediakan yaitu berupa rompi, helm dan sarung tangan yang telah digunakan untuk seluruh pekerja.

Negara sebenarnya telah mengatur perlindungan kepada tenaga kerja serta dengan memperketat persyaratan (administratif) untuk memperkerjakan seorang tenaga kerja. Pengaturan tersebut baik mengenai waktu kerja dan waktu istirahat, keselamatan dan kesehatan kerjanya (K3), maupun mengenai upah dan jaminan sosialnya (social savety net and social security) serta bentuk perlindungan lainnya harus dapat terpenuhi oleh perusahaan yang memperkerjakannya, oleh karena itu diberlakukan sanksi terhadap pelanggaran UU Ketenagakerjaan, disamping terdapat sanksi dan (konsekuensi) perdata, juga ada sanksi pidana serta sanksi bersifat administrative. Ruang lingkup perlindungan hukum terhadap pekerja/buruh menurut UU Nomor 13 Tahun 2003 tentang Ketenagakerjaan meliputi :

a. Perlindungan atas hak-hak dasar pekerja/buruh untu berunding dengan pengusaha b. Peerlindungan keselamatan dan kesehatan kerja

c. Perlindungan khusus bagi pekerja pekerja/buruh perempuan, anak dan penyandang cacat

d. Perlindungan tentang upah, kesejahteraan dan jaminan social tenaga kerja

\section{Faktor Penghambat Pelaksanaan Perlindungan Hukum Terhadap Pekerja Borongan Pembangunan Villa Permata Ariza di Kuta Selatan}

Pekerja Borongan mempunyai peranan yang penting tanpa adanya pekerja/buruh tidak mungkin perusahaan itu bisa berjalan dan berpartisipasi dalam pembangunan. Namun nasib buruk tidak mendapat perlindungan hukum yang cukup dari pihak pengusaha yang dapat menimbulkaan faktor penghambat dalam pelaksanaan perlindungan hukum terhadap pekerja borongan. Faktor penghambat itu timbul baik dari pekerja borongan, pengusaha dan pemerintah.

Untuk mengetahui Faktor-faktor penghambat dalam pelaksanaan perlindungan hukum terhadap pekerja borongan di Villa Permata Ariza, maka dapat ditinjau dari pihak-pihak yang saling berkaitan antara lain:

1. Pihak pekerja borongan

a. Rendahnya Pendidikan

Pendidikan baik formal maupun informal memiliki tujuan untuk membantu manusia untuk berpikir dan cara pandang orang dewasa yang memiliki bobot atau nilai yang lebih baik daripada orang yang masih kanak-kanak. Jenis pekerjaan yang tersedia hanya menuntut pendidikan formal maupun informal. Pekerjaan yang tersedia hanya menuntut keterampilan khusus yang diperoleh berdasarkan pengalaman sehari-hari. Pekerja borongan rata-rata memiliki cara berpikir dan cara pandang yang masih lemah. Pekerja/buruh lebih suka pasrah dan menerima segala 
kebijakan yang telah ditetapkan oleh pengusaha. Sehingga pekerja/buruh yang berani berpikir kritis untuk memperjuangkan nasibnya sendiri belum bisa diwujudkan.

Dari hasil Observasi di lapangan tersebut dapat diketahui, bahwa pekerja/buruh yang mempunyai cara pandang yang sempit seperti diatas sering kita temui dan dapat dimaklumi jika dilihat dari latar belakang keluarga yang kebanyakan berasal dari keluarga miskin yang tidak mampu meneruskan sekolah sampai jenjang perguruan tinggi. Mempunyai pekerjaan dan memperoleh penghasilan merupakan sebuah kebanggaan tersendiri bagi pekerja/buruh yang rata-rata berpendidikan rendah.

b. Tidak memiliki serikat pekerja/serikat buruh

Kita mengetahui, bahwa pekerja/buruh itu sifatnya lemah, baik dari segi ekonomi maupun dari segi kedudukan dan pengaruhnya terhadap pengusaha. Oleh karena itu, akibatnya pekerja/buruh tersebut tidak mungkin memperjuangkan hak-haknya ataupun tujuannya dengan perseorangan tanpa mengorganisir dirinya dalam suatu wadah yang dapat membantu mereka untuk mencapai tujuan itu. Wadah tersebut dinamakan Serikat Pekerja/serikat buruh. Di dalam Undang-Undang No. 13 Tahun 2003, serikat pekerja/ serikat buruh diatur dalam Pasal 104 ayat (1) Undang-Undang No. 13 Tahun 2003 bahwa setiap pekerja/buruh berhak membentuk dan menjadi anggota serikat pekerja/ serikat buruh. Di dalam sebuah perusahaan serikat pekerja/serikat buruh sangat diperlukan karena serikat pekerja/serikat buruh sebagai wadah untuk menyalurkan aspirasi kaum pekerja/buruh dan memperjuangkan, membela serta melindungi hak dan kepentingan pekerja/buruh serta meningkatkan kesejahteraan pekerja/buruh dan keluarganya.

c. Terjadi perselisihan hubungan industrial Perselisihan hubungan industrial diatur dalam Pasal 136 ayat (10 UndangUndang No. 13 Tahun 2003 bahwa penyelesaian perselisihan hubungan industrial wajib dilaksanakan oleh pengusaha dan pekerja/buruh atau serikat pekerja/serikat buruh secara musyawarah untuk mufakat.

Perselisihan hubungan industrial yang terjadi di kontruksi borongan, berdasarkan penelitian, perselisihan yang terjadi antara pihak

d. Tidak ikut dalam Jaminan Sosial Tenaga Kerja

Jaminan Sosial Tenaga Kerja merupakan suatu perlindungan bagi tenaga kerja dalam bentuk santunan berupa uang sebagai pengganti sebagian dari penghasilan yang hilang atau berkurang sebagai akibat peristiwa atau keadaan yang dialami oleh pekerja/buruh. Jamsostek diatur dalam Pasal 99 ayat (1) UndangUndang No. 13 Tahun 2003 yang meyatakan bahwa setiap pekerja/buruh dan keluarganya berhak untuk memeperoleh Jamsostek.

\section{Kesimpulan}

\section{PENUTUP}

Berdasarkan hasil penelitian dan pembahasan mengenai Perlindungan Hukum Terhadap pemborong di Villa Permata Ariza wilayah Kuta Selatan dapat disimpulkan sebagai berikut :

1. Bentuk perlindungan hukum

Bentuk perlindungan hukum terhadap pekerja tertuang dalam Undang-Undang Nomor 13 Tahun 2003 tentang tenaga kerjaan yang mengatur perlindungan tenaga kerja yaitu 
meliputi, perlindungan khusus bagi tpekerja/buruh perempuan, anak dan penyandang cacat. Perlindungan tentang upah bagi tenaga kerja.

Jika dilihat dari segi perjanjian kerja yang di sepakati antara dua belah pihak yaitu perjanjian kerja yang dibuat secara lisan yang telah didominasi pihak pengusaha dalam menentukan kebijakan, perjanjian yang dibuat secara lisan menempatkan pihak pekerja borongan dalam posisi yang lemah. Dalam upaya perlindungan hukum terhadap para pekerja juga tidak sesuai dengan peraturan perundang-undangan yang berlaku.

2. Faktor-faktor penghambat perlindungan hukum

Tidak ikut dalam Program Jamsostek menyebabkan kesejahteraan pekerja harian lepas dan keluarganya kurang terjamin pada saat pekerjaharian lepas kehilangan sebagian atau seluruh penghasilannya akibat terjadinya resiko sosial.

Dalam UU No. 13 Tahun 2003 tentang Ketenagakerjaan, secara normatif ada jaminan terhadap hak-hak pekerja borongan namun tidak implementatif dan sulit dilaksanakan. Pada implementasinya masih ada ratusan perusahaan yang tidak mematuhi program jaminan sosial dari BPJS Ketenagakerjaan (BPJSTK), perbedaan peraturan perusahaan dan peraturan pemerintah, serta tidak ada sanksi pidana secara spesifik bagi perusahaan penyedia jasa yang melakukan pelanggaran menjadi faktorfaktor pokok yang menghambat perlindungan hukum terhadap pekerja borongan pembangunan Villa PermataAriza di Kuta Selatan.

\section{Saran}

Berdasarkan simpulan hasil penelitian, saran demi perbaikan atas kondisi perlindungan hukum terhadap pekerja borongan pembangunan Villa PermataAriza di Kuta Selatan perlu di kemukakan yaitu:
1. Pekerja/buruh seharusnya memiliki pengetahuan dan informasi yang cukup tentang peraturan ketenagakerjaan. Dengan pengetahuan dan informasi yang cukup tentang peraturan ketenagakerjaan minimal dapat membantu pekerja tidak dihadapkan pada penyimpangan ketenagakerjaan yang dapat merugikan hak dan kepentingan pekerja harian lepas.

2. Pengusaha atau pemilik bangunan harus tetap memperhatikan hak-hak pekerja borongan agar perlindungan hukum mengenai hak pekerja borongan yang dibuat didalam perjanjian kerja dapat terpenuhi dan memperhatikan kesejahteraan pekerja borongan. sebagai pemberi kerja seharusnya dapat mematuhi peraturan ketenagakerjaan yang berlaku sehingga tercipta iklim kerjasama yang sehat dengan berdasarkan kesadaran yang tinggi untuk melakukan dan berusaha mengadakan perbaikan upah, syarat kerja, hubungan kerja yang baik, keselamatan kerja serta jaminan sosial dalam rangka perbaikan kesejahteraan pekerja dan keluarganya.

3. Pemerintah harus lebih aktif untuk mengadakan penyuluhan dan pengawasan ketenagakerjaan secara rutin terhadap perusahaan besar maupun perusahaan kecil agar pihak pengusaha maupun pekerja/buruh dapat memperoleh pengetahuan dan informasi mengenai ketenagakerjaan.

\section{DAFTAR PUSTAKA}

Undang-UndangNomor 13 Tahun 2003 tentang Ketenagakerjaan

Soedarjadi, 2008, HukumKetenagakerjaan Di Indonesia, (Yogyakarta :PustakaYustisia), hal. 5

Sendjun H Manululang, 1998, PokokPokokHukumKetenagakerjaan Di Indonesia.

Pius Partanto, 2001, KamusIlmiah Popular. Surabaya :Arkola, hal. 345. 
DwiyantoAgus, 2006, ReformasiBirokrasiPublik di Indonesia, Yogyakarta: GadjahMada University Press. hal. 45 .

Hartono,

Judiantoro,

SegiHukumPenyelesaianPerselis ihanPerburuhan, (Jakarta:

RajawaliPers, 1992), hal. 10.)

Tjepi F. Aloewic, Naskah Akademis Tentang Pemutusan Hubungan Kerjadan Penyelesaian Perselisihan Industrial, Cetakan ke-11, (Jakarta: BPHN, 1996), hal. 32 .

Kartasapoetra, dan Rience G. Widianingsih. Pokok-pokok Hukum Perburuhan. Bandung, Armico, 1982, hlm. 73

Lalu Husni. Pengantar Hukum Ketenagakerjaan Indonesia. Jakarta, Raja GrafindoPersada, 2000, hlm. 35.

Djumadi. Hukum Perburuhan Perjanjian Kerja. Jakarta, Rajawali Pers, 2002, hlm. 36.

Asikin, Zainal. 2004. Dasar-Dasar Hukum Perburuhan. Jakarta: PT. Raja Grafindo Persada.

Widyadharma, Ignatius R.2003. Tentang Ketenagakerjaan di Indonesia.
Semarang: Badan Penerbit Universitas Diponegoro.

Wibowo, Bonoe S. 2002. Himpunan Peraturan Perundangan Ketenegakerjaan. Yogyakarta: Andi

Muhammad, Abdul Kadir. 2004. Hukum dan Penelitian Hukum.

Fenny Nathalia Khoe, 2013, Hak pekerja yang sudah bekerja namun belum menandatangani perjanjian atas upah ditinjau berdasarkan Undang-Undang Nomor 13 tahun 2003 tentang Ketenagakerjaan, Jurnal Ilmiah Mahasiswa Universitas Surabaya Vol.2 Nomor 1

\section{Peraturan Perundang-Undangan:}

Undang-UndangNomor 13 Tahun 2003 Tentang Ketenagakerjaan dan Peraturan Pelaksana dari perundangundangan di bidang Ketenagakerjaan. Undang-Undang Nomor 13 Tahun 2003.

Undang-Undang Nomor 3 Tahun 1992 Tentang Jaminan Sosial Tenaga Kerja

Undang-Undang Nomor 21 Tahun 2000 Tentang Serikat Kerja atau Serikat Buruh 